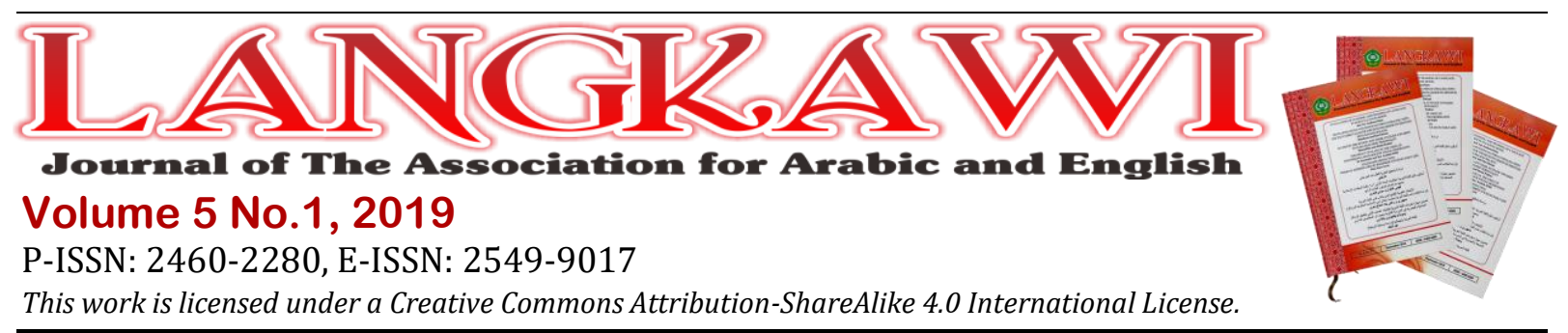

\title{
The Influence of Greek Philosophy on The Development of Arabic Grammar
}

\section{Mahyudin Ritonga}

Universitas Muhammadiyah Sumatera Barat, Indonesia. Email: mahyudinritonga@gmail.com

ARTICLE INFO
Keywords:
Influence; Greek Philosophy; Arabic
Grammar
How to cite:
Ritonga, M. (2019). The Influence of
Greek Philosophy on The
Development of Arabic Grammar.
Langkawi Journal of The Association for
Arabic and English, 5 (1), 13-25
DOI:
http://dx.doi.org/10.31332/lkw.v5i1.1135

\begin{abstract}
This paper is intended to disclose the interrelationship between Greek philosophy with the development of nahwu. The research is based on literature data, and the collected data are classified and analyzed using the inductive and comparative method. The research results show that nahwu development is not apart from the influence of philosophy. The interconnection has occurred since the period of al-Muqaffa who has translated many works of Aristotle and Plato which al-Khalil makes as a reference in arranging nahwu principles. The influence of philosophy on nahwu can be identified in two things, which are in methodological and terminological aspects.
\end{abstract}

\section{Introduction}

The main motivation of nahwu drafters is merely to prevent expression error (lahn) in the Arabic language. The occurrence of lahn becomes a serious problem, so a language principle which can integrate language system among the Arabs is needed. Ulama are concerned about the authenticity of the Arabic language that will implicate in contamination of al-Quran reading and comprehending method. Therefore, Ali bin Abi Thalib instructs Abu al-Aswad al-Duali to arrange a basic principle of the Arabic language that will be a reference for the Arabs and the use of the Arabic language.

Since its emergence, nahwu is known as never apart from other studies, such as tafsir, hadith, fiqh, kalam and other disciplines (al-Fadhliy, 1986). This can be understood because the various fields of science have a close relationship with Arabic language and all the rules existing in the Arabic language. In the development of Nahwu, there is relatively varied dynamics, in which the dynamics of Nahwu generates different views between two big genres in Nahwu, namely Basrah and Kufah (Yaacob, 2014). This different thinking patterns are certainly influenced by various aspects such as culture, politics, socio-culture and other factors out of Arabic language.

This paper will not describe the different perspectives of Basrah and Kufah studies because that aspect has been reviewed by Asrina in Khilâfiyah Nahwiyyah: Dialectics of Thinking of Nahwu of Basrah and Kufah in the Note of Ibn al-Anbari 
(Asrina, 2016). This article also does not discuss the opinions of experts who support and reject the influence of philosophy on nahwu because it has been reviewed by Abdillah (Abdillah, 2003).

But this paper will focus on the interconnection of philosophy with the development of nahwu, in which this is based on the statement of al-Jabiri (al-Jabiri, 2009) that "if philosophy is referred to as the miracle of the Greeks, then the knowledge of the language is the miracle of the Arabs. This statement implies that there is a close relationship between philosophy with nahwu, and it also shows that the different views between ulama of Basrah and ulama of Kufah cannot be separated from the philosophical genre they follow.

\section{Literature Review}

\section{a. Development of Nahwu and its Focus of Study}

Since the early development of science in the Islamic world, ulama have paid great attention to the development of nahwu as a science. In its early time, nahwu consists only of several principles obtained by ulama from their observation on the Arabic language used by the Arabs at that time. As narrated, the first things taught by Ali to al-Dualy are the division of words (al-kalimat), inna wa akhwatuha, idhofah, ta'ajjub, istifham, and imalah. The development of nahwu is at its peak during the period of Sibawaihi and al-Kisa'i in which ulama study extensively and thoroughly all rules of Arabic language. Then, they express different, various theories and opinions of a discussion of nahwu and they establish separate genres, which are Bashrah genre, Kuffah genre, and Baghdad genre (al-Thanthawy, 1999).

The principles in Nahwu are al-Sima', al-Qiyash, al-'amil, and ijma'. Al-Sima'as expressed by (Mumtahen, 2015). This al-Sima' principle is more closely related to culture issues than a scientific system. The culture here according to Ritonga (Ritonga, 2016) is that, in Arabic classical tradition, there is a certain group that is believed to have authority in the linguistic matter, in which the group with such authority is Arab community who live in a rural area, often referred to as "ahl alBadwi". The next principle is al-Qiyash. This principle emerges and is used in formulating linguistic rules along with the commencement of basic formulation of nahwu. In the early time of nahwu, al-Qiyas has a very simple meaning, that is: "to create a language considered as correct to be the standard or analogy and model to form a certain sentence (Safa, 2008).

The third principle is 'amil, that is matters that cause or influence other matters in its $i^{\prime} r a b$. Speculative and rational natured nahwu issues emerge subsequently. For example, when in the early emergence of nahwu, there is formulation of "al-Fa' il or alMubtada" formulation, both of them serve as subject, with rafa'-i'rab as its status mark, then al-Khalil asks a question; what or who makes that mubtada' or fa'il read asrafa", he then arranges his new theory referred to as "amil".

The next one is ijma' principle, in which in the field of nahwu is an agreement between ulama of Bashrah and ulama of Kufah(Rahman, 2010). An example of ijma' is a Bashrah and Kufah agreement of nuhat (expert in Nahwu) in the case of khabarmubtada' if it consists of adjective, then that khabar contains dhamir referring to mubtada', like the attribute of both sentences with position as khabar mubtada', but in ijma', both of them contains dhamir that returns to mubtada'. 


\section{b. Philosophy and its Scope}

Aristotle is an icon of rationality. He is the founder of thinking method that is arranged in premises and then drawn into a conclusion. What Aristotle does is called logics. In his theory, Aristotle always makes a rational approach. This is reflected in each of his works. Even the universe, according to him, is not controlled by something that is coincidental. The movement of this universe is subject to rational laws (empirical observation and logical grounds) (Barbosa, 2015).

Mantiq is an invention of Greek ancient philosophers since the $5^{\text {th }}$ centuries BC. The founder is Socrates, continued by Plato and completed by Aristotle, who composes this science in orderly discussions and it is created from philosophy science. Therefore, Aristotle has given a title as as the first teacher of science (Wanis, 2006). Aristotle's work of logic is named To Organon by his disciple, Andronikos of Rhodos (Corazzon, 2018). In his works, Aristotle, according to Nur (Nur, 2011) discusses the category, structure of language, scientific verification, differences in essential attribute, and non-essential attribute (essential attribute), as a unity of thinking.

The development of thought in Islam is not independent of other influences, but many also adopt existing ideas in Greece (Ibrahim Madkur, 2015). Munir explained that even so, it does not mean that Islam adopts raw Aristotelian or Plato's thoughts (Munir, 2011). Based on these two arguments the author asserts that the development of grammatical Arabic is also not separate from the adoption of Greek philosophy.

\section{Method}

The approach used in this study is descriptive qualitative, namely research data in the form of words rather than numbers. The research method used is library research, where researchers use data sources from documents that contain research objects such as books, articles, magazines. The researcher is only dealing directly with the text contained in the data source, not the field eyewitness, in the form of events, people or other objects. Researchers also do not go anywhere, except only dealing directly with sources that already exist in the library. Data analysis was carried out in two stages, namely 1) since data collection to see the essence and focus of research, 2) analysis to see the relationship between nahwu and philosophy.

\section{Findings and Discussion}

Language and philosophy are two branches of social science that have a close relationship in which there is a statement "using language is the same as playing logics (Shah, 2005), (Moss, 2012). Linguistic and philosophical theories are studies that are a close one to another and need one to another. From this point, it is not surprising that in its early development, nahwu theory becomes an event of debate on the involvement of Greek philosophy science. Therefore, the emergence of nahwu theories will be viewed as unusual if it is merely natural and social phenomena(Zaid, 1994). Philosophy needs language to articulate its intention and meaning, including nahwu that is influenced by philosophy.

As in Aristotle's formulation, human is an animal rationale. This statement bears the meaning that the dividing line between human and animal is ratio. Aristotle realizes that language is also an important attribute of human, even 
language is the center of main attention in his philosophical reflection (Soames, 2010). However, as explained previously, he places language at the third level (oral language) and at the fourth level (writing) among four anthological levels. Language is arbitrary symbolism of ratios at the second level as a natural copy of external reality. In this shorting, it is clear that in Aristotle's view that persists for a very long time, language is nothing more than an arbitrary and conventional means of expression for absolute and universal natured ratios. Rationality does not depend on language and, on the contrary, language depends on the ratio. The view that ratio is independent of language recently becomes obsolete. Thinkers and scientists start to believe that thinking ability is closely related to language. Blomfield states that thinking is talking to oneself (Bloomfield, 2010), (Adamson \& Taylor, 2005), (Schwartz, 2007), (Duan, 2017).

A more radical view of the connection of ratio and language does not merely state that the ability to think is closely related to language, however, it further assumes that human rationality is determined by language. Language itself is seen not as singular but diverse (Setiawan \& Sudrajat, 2018). It has been mentioned that the second hypothesis of the Sapir-Whorf hypothesis, that is the linguistic relativity principle, supports this view. In reality, there are other sources for the tendency of this view of which influence is even more widespread in the arena of debates of philosophy and contemporary social sciences than the influence of the Sapir-Whorf hypothesis (Troyer, 1994), (Hussein, 2012).

De Saussure reveals that it is langue that gives form to the human mind (Saussure, 1974). Before it is expressed in a sign of language, human mind is a mixed and non-permanent mass, like "fog whose elements cannot be restricted." Sound elements in the sign of language are not merely the materialization of a finished concept; on the contrary, the concept is not the spiritualization of the unit of sound that has also been finished. At the same time, there is a separation of the mind mass which then acts as a marker and sound element which subsequently acts as a marker, and both of them are simultaneously linked to form a sign of language (Saussure, 1974). The sorting of the mind mass and the sound element and its attachment form the language sign that occurs arbitrarily, which ensures the bond between the signifier and the marker is not a natural relation, but the system of internal difference in the structure of the langue itself. Since the formation of the language sign occurs arbitrarily, each langue system will result in non-exactly the same sorting. The word nasi in Indonesia language, for example, is not exactly paired with the word "rice" in English, because "beras" has a contrast with "nasi", "padi", and "gabah", while "rice" is not.

Ludwig Wittgenstein formulates a different way of viewing the human mind. For him, all aspects of the human mind cannot be separated from the use of language. Wittgenstein's philosophy is divided into two periods: first: Tractatus Logico-Philosophicus (1922), this theory reveals the picture theory and the logics of language. The essence of language is a logical representation of the reality of the world, which is composed of propositions and describes the existence of a factual event (state of affairs) (Wittgenstein, 2015). In other words, the use of language in the analysis of philosophical theory must be able to reveal objectively the facts of the world, and this must be done by using language based on logic. With language, 
something to say can be said clearly, while to explain something that cannot be said, Wittgenstein uses metaphors and analogies.

According to Wittgenstein, based on the picture theory, metaphysics does not reveal the reality of fact, thus it is meaningless. In relation to God's expression, aesthetics, and ethics, Wittgenstein calls it mystical (Mckeon, 2004). Therefore, in this first theory, Wittgenstein bases on an ideal language that qualifies logics. The second period, Philosophical Investigations (1953), this theory contains the theories of meaning use and language games.

Mean while, in the axiological aspects, language use is as a means of communication in expressing a meaning. In order to know the essence of meaning contained in a language expression, one must understand the values contained in human life in relation to the use of the language expression. From an understanding of the concept of language reviewed ontologically, epistemologically and axiologically above, it indicates that there is a causal relationship between human and language, that is human as the cause and language as the result (Wittgenstein, 2015). Based on this fact, any value inherent in language is determined by human existence as the subject, and value can be understood by human through common sense and consciousness. Therefore, in order to study the meaning of language, we should observe human life in relation to the rules of language usage. Wittgenstein has shown that language cannot be separated from human life. One cannot understand and describe how the reality of life in this world without language, and cannot force anything without language. A human cannot get out of the language system to see the world objectively. The meaning of one's thoughts and expressions cannot be separated from language. In order to know and ask a name or expression, we must see how the use of the name or expression is in the language game.

In the codification of the Arabic language, the main purpose is not merely bookkeeping in the sense of recording, codification is a transition from an unscientific Arabic language to a scientific language. The collection of vocabularies of the language and the determination of the way of derivation and its morphology, the determination of the rules of structure and the selection of signs to eliminate unclearness in writing, all of which according to al-Jabri are not only called the creation of linguistics, but also the creation of a new language namely fushha Arabic language (al-Jabri, 2009).

It is identical to whether we associate the collection and rules of this language is intended to save the language of the Qur'an from irregularities and harassment, due to the spread of lahn in the new Islamic society during the era of codification in which the majority are not Arabs and do not understand the Arabic language, or can be associated to the needs of the Persians to study Arabic language in order to maintain their position after the Arabization took place as often mentioned as a contemporary analysis (Syamsuri, 2011), (Hafid, 2016). The final conclusion remains one, that the process changes the Arabic language that is originally considered unscientific to a scientific language, a language that is subject to a system which was also followed by other objects.

Furthermore, something remarkable about the Arab expansion is that it lies more on the Arabization movement of provinces conquered by its military attacks. The Arabic language is not only a means of expression daily used by the people who 
live from Persia to the Pyrennia Mountain but also the peak of cultural instrument that presses ancient cultural languages such as Coptic, Aramaic, Greek, and Latin(Lewis, 2002). The widespread use of Arabic language shows an indication that the difference between the conquering Arab and the conquered Arab is almost indistinguishable, while people who speak Arabic language and embrace Islam find themselves in a group, and the term Arab was once used for the meaning nomadic that becomes the origin of that language or for aristocratic meaning which has no economic and social meaning.

The role of nuhat at that time is the role of a researcher who observes the language as a symptom as it is (descriptive). This means that, from the observations, agreements take place between researchers about the observed object until it becomes a separate theory or law of language. This leads to a debate about the urgency of nahw, because it is possible that nahw will keep people away from the initial goal of learning the language itself.

Al-Khalil (Al-Farahidi, 2002)for example, in expressing the theories about language written in the book of al-jumal, reveals the phenomena more descriptively (Khaqani, 2004). When he observes many same letters but in different uses, he then records them as a new phenomenon that is important to take a note (Saehudin, 2014). What is written then becomes important information for later nahw reviewers including Sibawaih (Pribadi, 2017), (Dihe, 2018). Further discussions develop and produce derivative theories as later expressed into the Al-Kitab of Sibawaih (Utsma bin Qanbar, 1988).

The codification of Arabic language is not just bookkeeping in the sense of notes. Codification is a transition from an unscientific language into a scientific language, the collection of vocabularies of language and the determination of rules of structure and the selection of signs to eliminate unclearness in writing (al-Jabri, 2009). All of which are not called creation of a new language, that is the Arabic language science, but also the creation of language, that is Fushha Arabic language. It is from Al-Khalil and his followers that the conceptualization of Arabic language uses the method of making and composing it into standard and rigid categories (Qaddarah, 1983), not the rules to combine its fragments and to organize its internal life by maintaining the possibility of development and renewal.

Sibawaih discusses in greater detail and in more detail in the Al-Kitab than what al-Khalil discusses in the book of al-Jumal as his teacher. Sibawaih is able to explain the phenomenon of a predicate in a sentence that may appear twice in a sentence or commonly referred to as fi'il which needs two maf ul. This kind of study is not discussed by al-Khalil. Therefore, the next question arises, where does the originality of this term come from? On the other hand, Sibawaih is mentioned to be al-Khalil's disciple (Chaqoqo, 2015). What instruments are used by Sibawaih to interpret this teacher's thinking?

Two implications arise here. First, regarding possible inclusion of terms from philosophy science (Ya'qub, 1986). And both implications of this detailed discussion will, in fact, keep a word or phrase away from its meaning. This is the ground of criticism of the later nahw ulama such as Ibn Madha in ar-Radd ala al-nuhat (AlQurthubi, 1983). The debates on these two implications have never been resolved because of arguments arising from the codification of nahw itself, for example, it is 
unable to provide a relatively newer solution. Ibn Madha, for example, is unable to challenge the theories developed by the early nahw ulama and instead receives much criticism after wards (Ardinal, 2013), (Arummi, 2015).

It is inevitable that, at the beginning of its development, nahw is in contact with the revival of science which is marked by the transition of knowledge from the outside into Islam through translation movement. Like Kalam and Ushul Fiqh sciences, nahw grows and develops in a very rational environment (Rosyidah, 2011). As is known, nahw is geographically built in the area of Iraq and experienes a power shift from the Umayyad Dynasty to the Abbasid Dynasty which at that time has a rational climate conducive enough to the use of pure ratios (al-aqlal-khalis) in the nahw study (Yaacob, 2013). The book of Sibawaih entitled al-Kitab, for example, is almost built on the foundation of ta'lil as a logical consequence of the study developed therein (Utsma bin Qanbar, 1988). Even the dialogical method applied therein generally begins with 'illat.

There are also examples of the use of qiyas. This shows that the dimension of the tradition of applying mantiq in explaining nahw problems has existed since the early growth of nahw as a discipline, which is the third century reaches its peak and in the fourth century becomes a trend in the nahw study. That is why Syahin states that the lughawi need not pretend to be ignorant of ta'lil after Sibawaih, that has been completely influenced by mantiq and practically exaggerated in nahw study, thus nahw in their books becomes a kind of reasoning training (Syahin, 1993). This means that nuhat develops a rational approach in the nahw study.

Their rational approach can be seen from Sibawaih's explanation of the nominal phrase constructed by explained-explanatory law in which the explanatory is readrafa' and read nashab (Utsma bin Qanbar, 1988). It should be noted that something is attributed to something that it is it. This attribute includes the substance (Utsma bin Qanbar, 1988), like the expression hadza zaydun ath-thawilu which means Zaid is tall, sometimes it is it and this attribute does not include the substance like the expression hadza Zaydun dzahiban that means Zaid is gone.

The word al-shaghir in the nominal phrase ahmadu al-shaghir and the word ahmad in the nominal phrase ahmadu dzahiban are respectively read rafa' and nashab (Utsma bin Qanbar, 1988). The first example is read rafa' because it gives the attribute (explanatory) as well as the person Zaid (explained) himself. Mean while, the second is read nashab because it gives the attribute (explanatory) Zaid. However, the description of this attribute is not Zaid (explained) himself.

Here Sibawaih talks about the attribute and the substance, in which attribute is the substance itself. This is seen from the phrase "it is it" (the attribute is substance) and this reminds us of Aristotle's thought that the first usage is mind (attribute) and mindful (substance) (Madkur, 2000). The logical consequence of such an approach will be seen in their highly appreciative attitude towards mantiq which is later spread to nahw, either through Greek Philosophy, Kalam or Ushul Figh which in fact the volume of pure ratio usage (al-'aql al-khalis) is relatively high. The bias broader than this rational attitude is the growth and development of philosophical studies such as as'amil, ta'lil, qiyas, etc., which are regarded as the pillars of nahw structure.

The rational approach is later criticized by modern linguists. The reason is that the dimension of the tradition of applying 'amil, qiyas, $t a$ 'wil has generated pluralism 
of thought and branching of a nahw problem, which in turn draws nahw into a debateful study. This makes nahw unable to function effectively as a means of thinking and understanding of the discourse of the Arabic language.

Observing nahw books will look very normative patterns (mi'yari), which means that $n a h w$ is the result of acceptance of a set of rules about the use of language, in the form of pronunciation, spelling, grammar. This can be proved by the following two points, first, nahw is subject to the rules of the nuhat's thought, which leads to the truth of language according to the rules devoted to the language. From this comes the term syadz (anomaly) or language that deviates from grammatical conventions (Darwiysh, 1987).

Second, nahw is seemed to be a reasoning exercise as a result of penetration of mantiq logic into it, which is welcome by nuhat excessively. This is apparent in the discussion of qiyas, taqdir (appraisal), 'amil, illat such as the staged inherent studies of the nuhat of Bashrah, etc. Therefore, the discussion of such nahw is closer to the mantiq than to the nahw itself, which in later eras emerge linguists who criticize the 'illat issues in nahw as well as Syauqi Daif who assumes that 'illat in the nahw study would bring up another 'illat that forms such continuous chains of 'illat (Dhayf, 2013). Ibn Madha emphasizes the use of the 'amil theory which results in difficulty of the hadzf and taqdir theory in understanding nahw (Al-Qurthubi, 1983).

De Boerstates that nahw has been in touch with Greek philosophy since the time of Ibn Muqaffa $(163 \mathrm{H})$ by translating Greek works and has them spread among the nuhat and used to determine the basis of nahw (Boer, 1993). He further confirms his point by pointing out that each of his translations has been given to al-Khalil. He always reads each of Muqaffa's translations (Boer, 1993). These two figures often discuss issues of Arabic language and Greek philosophy. This shows that al-Khalil in writing the rules of nahw has studied Aristotle's philosophy which is translated by Muqaffa.

Confirmed by Ahmed who quotes Versteegh opinion with statement that Aristotle's formal logics (al-manthiq ash-shuri) influences the nahw developed by nuhat (Ahmed, 2008), (Malink, 2015). Al-'Akili reveals that the influence is primarily seen in a number of nahw terminologies and noun classification system (Al-'Akili, 2014). His study concludes that the core of nahw's preoccupation by Greek philosophy can be seen in two ways: methodology (manhaj) and terminology (mushtalahat) (Back, 2008). Merx shows there are several nahw theories that have Aristotelian roots, among others: division of word types (ism, fi'l and harf) which is considered to mimic the Greek concept of anoma, rhema and sundesmos; i'rab concept,mimicking the Greek words hellenizein, hellenismos, or declension; the basic concept of gender (al-jins) that distinguishes men and women, imitating the concept of genos: the concept of zharf (adverbs of time and place), mimicking Aristotle's concept of space and time; terms associated with two Greek terms, hexis and diathesis, the concept of khabar (predicate), influenced by the concept of kategoroumenon.

In line with the opinions above, Schock has an assumption that the concept of nahw is similar to some Greek terminologies, such as sharf with klisis (flection), i' rab with hellenismos (declension), musnad ilaih with hupokeson (subject), and khabar with kategoroumenon (predicate) (Schock, 2015). Confirmed by historical data obtained from the classical literature, in the classical study of nahw, there is an influence of 
philosophical studies developed at the time. Even if explored further, the terminologies are actually not found in nahw, Schock seems less objective in determining the problem.

Most of the ulama also argue that in the Age of Ignorance, not all tribes are able to speak language by achieving the degree of lughah 'aliyah. Ryding reveals the tribes that inhabit the central part to the northern part of the peninsula considered the most eloquent, such as Hijaz, Kinanah, Hudzail, Ghatfan., Hawazin, Sulaim, hayyi', Tamim, Asad, Qais and other tribes (Ryding, 2005). Ibn al-'Arabi, as quoted by alSuyuti (Mukrim, 1989) finds that Arabic language quotes and follows those tribes. Tamim and Asad are tribes whose language are most widely used, followed by Hudzail tribe, part of Kinanah and Thayyi', in which Bashrah nahwu uses much of their languages as reference in setting the rules of nahw.

Methodologically, the early nuhat of Bashrah develop their own method, which is now referred to as empirical method (al-manhaj at-tajribiy), by collecting the materials of nahw through language deriving directly from the language speakers in the environment of Arabic rural areas of which purity of language is relatively reliable and trustworthy (al-mawtsuqbihim) (Al-Rajihi, 1979). From here, some rules are set through induction process. In addition, the emphasized ta'lil cannot be separated from the previously collected languages.

In this case, Ma'n states that, in the first period of nahw formation, nuhat of Basrah uses empirical method (Ma'n, 2001). Their attention is to the collection of language that develops in the community without making judgment that "this language okay or not okay" or "this language is true or not true". The effort means that Nahwu in its early period is not built on the foundation of grammatical rules or conventions.

Mean while, Lewis also adds the classical writings on Islamic politics, which also influence the political development in Europe, derived from the first translations and adaptations of Ancient Greek texts into Arabic language, especially Plato's and Aristotle's writings in politics, in which Muslim philosophers are keen to correlate between the philosophical doctrines they have inherited from ancient times with Islamic teachings (Lewis, 2002). In confronting these dilemmas, they generate philosophical works that often contain views on political issues. When they do this, they include new vocabularies or terminologies derived from Arabic language equivalent to Greek political terms and mix them with more original terms to express religious-political traditions in Islam.

The people of Bashrah are in direct contact with philosophical studies that have become their scientific traditions, so that nahwu that grows rapidly among nuhat of Bashrah is much influenced by Greek thought, especially in searching 'illat and root of problem in the formulation of rules. It is reasonable when we view that it is close to the study of philosophy in Jundi Shapur, but this influence is different from the influence in view of Merx and Schock. The influence the author means is that the study of philosophy is an inspiration for nuhat to search for empirical data in the preparation of rules, especially nuhat of Bashrah, like al-Khalil who makes friend with al-Muqaffa, a translator of Greek works who always give his works to al-Khalil so that Bahsrah uses empirical approach more than just sima'i like nuhat of Kufah 
who are interested more in hadith and fiqh studies. This is most noticeable when we look at the writings of nuhat of Bashrah like al-Jumal, al-Kitab.

\section{Conclusion}

From the discussion above, we may conclude that the use of philosophical elements in nahwu study has occurred since the time of al-Muqaffa. The nahwu expert who are affiliated with Bashrah always consider philosophy in establishing nahwu theories, in which it is different from ulama of Kufah who conduct more intensely in the study of hadith.

The influence of philosophy on nahwu is seen in two matters, first, in terms of methodology, and, second, in terms of terminology. There are some nahwu theories that have Aristotelian roots, among others: a) division of three types of words in nahwu, that are ism (noun), fi'il (verb), and harf (letter), this concept is influenced by onoma, rhema and sundesmos contained in the Greek philosophical concept, b) the concept of i'rab as contained in nahwu is identical with hellenizein, hellenismos existing in Greek philosophy, c) the concept of gender (al-Jins) that distinguishes between men (mudzakkar) and women (mu'annats) is based on the concepts of genos of Greek philosophy (d) the concept of zharf (place and time) is influenced by the space and time in Greek philosophy), e) the term al-hal is influenced by hexis and diathesis, and f) the concept of al-Khabar is influenced by the concept of kategoroumenori.

The results of this study have not revealed in detail the aspects of Arabic which are influenced by Greek philosophy and their forms of influence, as well as the linguists who link the two studies are still limited, readers and observers of language studies and philosophical studies should be able to express this to enrich scientific sources .

\section{References}

Adamson, P., \& Taylor, R. C. (2005). The Cambridge Companion to Arabic Philosophy. Cambridge: Cambridge University Press.

Ahmed, Z. (2008). Essentials of Arabic Grammar for Learning Quranic Language. Pakistan: DARUSSALAM.

Al-'Akili, H. (2014). al-Fikr al-Nahwy fi Dhaw'i al-Manthiq al-Aristhy. Jayl Al-Dirasat Al-Adabiyyah Wa Al-Fikriyyah, 23-35.

al-Fadhliy, A. H. (1986). Marakiz al-Dirasat al-Nahwiyyah. Yordania: Maktabah alMannar.

Al-Farahidi, A. (2002). Kitab al-'Aiyn. Beirut: Dar al-Kutub al-'Ilmiyyah.

al-Jabri, M. A. (2009). Takwin al-'Aql al-'Araby. Beirut: Dar al-Thali'ah.

Al-Qurthubi, I. M. (1983). al-Radd 'Ala al-Nuhat. Kairo: Dar al-Ma'arif.

Al-Rajihi, 'Abduh. (1979). al-Nahw al-'Araby wa al-Dars al-Hadits: Bahts fi al-Manhaj. Beirut: Dar al-Nahdhat al-'Arabiyyah.

al-Thanthawy, A. (1999). Nasy'ah al-Nahw wa Tarikh Asyhar al-Nuhat. Kairo: Dar alMa'arif. 
Ardinal, E. (2013). Pemikiran Syauqi Dhaif dan Upaya Pembaharuannya di Bidang Pengajaran Nahwu Telaah Buku Tajdid al-Nahwi. Jurnal Islamika, 177-190.

Arummi, A. (2015). Ibnu Madha dan Revolusi Nahwu Ala Madzhab Andalusia. CMES, 91-100.

Asrina. (2016). Khilafiyah Nahwiyyah: Dialektika Pemikiran Nahu Basrah dan Kufah dalam Catatan Ibn al-Anbâri. MIQOT, 410-430.

Back, A. (2008). Islamic Logic.

Barbosa, M. F. M. (2015). A Brief way on Philosophy of Language: from Plato to PortRoyal Grammar. International Journal of Language and Literature, 61-70.

Bloomfield, L. (2010). An Introduction to The Study of Language. New York: Henry Holt and Company.

Boer, T. De. (1993). History of Philosophy in Islam. London: Luzac.

Chaqoqo, S. (2015). Sejarah Nahwu Memotret Kodifikasi Nahwu Sibawiyh. Salatiga: Press IAIN.

Corazzon, R. (2018). The Rediscovery of the Corpus Aristotellicum and the Birth of Aristotellianism. Theory and History of Ontology, 41-51.

Darwiysh, A. (1987). Dirasat fi 'Ilm al-Sharf. Kairo: Maktabah al-Thalib al-Jami' ah.

Dhayf, S. (2013). Tajdid al-Nahw. Kairo: Dar al-Ma'arif.

Dihe, B. (2018). Konstruksi Pemikiran Sibawaih dalam Kajian Ilmu Nahwu. Rausyan Fikr, 89-111.

Duan, S. (2017). Bloomfield's Concept of Meaning. Journal of Language Teaching and Research, 343-348.

Hafid, K. (2016). Relevansi Kaidah Bahasa Arab dalam Memahami Alquran. Tafsere, 193-205.

Hussein, B. (2012). The Sapir-Whorf Hypothesis Today. Theory and Practice in Language Studies, 642-646.

Khaqani, M. (2004). al-Khalil bin Ahmad al-Farahidi fi Mizan al-'Aqliyyah alFarisiyyah. Majallah Al-'Ulum Al-Insaniyyah, 21-32.

Lewis, B. (2002). The Arabs in History. Oxford: Oxford University Press.

Ma'n, M. 'Abbad. (2001). al-Mu'jam al-Mufashshal fi Figh al-Lughah. Beirut: Dar alKutub al-'Ilmiyyah.

Madkur, I. (2000). fi al-Falsafah al-Islamiyyah. Kairo: Dar al-Ma'arif.

Malink, M. (2015). The Beginnings of Formal Logic: Deduction in Aristotle's Topics vs. Prior Analytics. Phronesis (Vol. 60).

Mckeon, M. (2004). Review of Tractatus Logico-Philosophicus . A Biannual Journal, 16.

Moss, S. (2012). The Role of Linguistics in the Philosophy of Language. Routledge Companion to the Philosophy of Language, 1-17. 
Mukrim, A. (1989). Jalaluddin al-Suyuthi wa Atsaruhu fi al-Dirasat al-Lughawiyyah. Kairo: Dar al-Fikr.

Mumtahen, M. (2015). al-Nahw wa Hikayah Nasy'atuh. Turats Al-Adaby, 69-74.

Nur, M. (2011). Islam dan Logika Menurut Pemikiran Abu Hamid al-Ghazali. Jurnal Al-Ulum, 47-62.

Pribadi, M. (2017). Sumbangan al-Khalil dalam Perkembangan Nahwu Arab. Adabiyyat: Jurnal Bahasa Dan Sastra, 73-93.

Qaddarah, F. (1983). Masail Khilafiyyah Bayn al-Khalil Wa Siybwaih. Kairo: al-Hay'ah al-Mishriyah al-'Ammah li al-Kitab.

Rahman, A. (2010). Sejarah Ilmu Nahwu dan Perkembangannya. Ada, 98-109.

Ritonga, M. (2016). Bargaining Kata di Dalam Al Qur'an: Kontroversi Ahli Terhadap Bahasa al Qur'an. Akademika, 229-254.

Rosyidah, I. (2011). Ideologi Madzhab Fiqih dan Sosial Politik dalam Kaidah Nahwu (Ibnu Madha dalam ar Rad ala al Nuhat). ULUL ALBAB Jurnal Studi Islam, 197218.

Ryding, K. (2005). Modern Standard Arabic. Cambridge: Cambridge University Press.

Saehudin, A. (2014). Originalitas Pemikiran Fonetik al-Khalil Ibn Ahmad al-Farahidi. Alfaz, 200-222.

Safa, N. (2008). Perbandingan Metode Nahwu Al-al-Akhfash dan al-Farra' dalam Kitab Ma'ani Alquran. Bahasa Dan Seni, 139-149.

Saussure, F. (1974). Course in General Linguistics. New York: McGraw-Hill Book Company.

Schock, C. (2015). Name (ism), Derived Name (ism mushtaqq) and Description (wasf) in Arabic Grammar. In Muslim Dialectical Theology and Arabic Logic, 329-360.

Schwartz, D. J. (2007). The Magic of Thinking Big. New York: Fireside.

Setiawan, J., \& Sudrajat, A. (2018). Pemikiran Postmodernisme dan Pandangannya Terhadap Ilmu Pengetahuan. Jurnal Filsafat, 25-46.

Shah, M. (2005). The Quest for the Origins of the qurrā' in the Classical Islamic Tradition. Journal of Qur'anic Studies, 200.

Soames, S. (2010). Philosophy of Language. Oxford: Princeton University Press.

Syahin, 'Abdushshabur. (1993). fi 'Ilm al-Lughah al-'Amm. Beirut: Muassasah alRisalah.

Syamsuri. (2011). Pengantar Qawa'id al-Tafsir. Sulesana, 91-97.

Troyer, G. van. (1994). Linguistic Determinism and Mutability: The Sapir-Whorf "Hypothesis" and Intercultural Communication. JALT Journal, 163-178.

Utsma bin Qanbar, (1988). al-Kitab: Kitab Siybawaiyh. Kairo: Maktabah al-Khaniji.

Wanis, 'Ali. (2006). Mabadi 'Ilm al-Manthiq. Beirut: Dar al-'Ilmi wa al-Tsaqafah. 
Wittgenstein, L. (2015). Tractatus Logic-Philosophicus. London: Kegan Paul.

Ya'qub, S. H. (1986). Mawqif al-Nuhat Min Falsafah al-Nahw. Malaysia: Islamic Universit.

Yaacob, S. (2013). Linguistic Argumentation and Logic: An Alternative Method Approach in Arabic Grammar. Argument, 405-427.

Yaacob, S. (2014). The Conflict of Theory in Arabic Grammar. International Journal of Social Science and Humanity, 1-4.

Zaid, N. H. A. (1994). Naqd al-Khitab al-Dini. Kairo: Shina li Nasyr. 